\title{
Decision Supporter for Determining Priority in Supply of Shoe Raw Materials Using the Simple Additive Weighting Method
}

\author{
Pendukung Keputusan Untuk Penentuan Prioritas Penyediaan Bahan Baku \\ Sepatu Menggunakan Metode Simple Additive Weighting
}

\author{
Ardila Sani \\ ARDILASANI@GMAIL.COM \\ Informatics Department \\ Faculty of Information Technology \\ Universitas Serang Raya \\ Banten, INDONESIA
}

Tb. Ai Munandar

TBAIMUNANDAR@GMAIL.COM

Informatics Department

Faculty of Information Technology

Universitas Serang Raya

Banten, INDONESIA

\author{
Akip Suhendar \\ Information System Department \\ Faculty of Information Technology \\ Universitas Serang Raya \\ Banten, INDONESIA
}

Corresponding Autor: Akip Suhendar

\begin{abstract}
More and more types of raw materials will be used to expedite the shoe production process, making it difficult for companies to determine the priority of raw materials. So that there are often advantages and disadvantages of raw materials during the production process, which causes changes in the budget of production costs that are not in accordance with the initial plan, resulting in decreased corporate profits. Decision Support System (SPK) is a system that can help someone in making decisions that are accurate and right on target. Many problems can be solved by using SPK, one of which is determining priorities in the supply of raw materials. There are several methods that can be used in building a DSS, including simple addtive weighting (SAW). The Simple Additive Weighting (SAW) method is often also known as the weighted sum method, by finding the weighted sum of performance ratings for each alternative of all attributes. This study discusses the making of a decision support system as a tool for determining priorities in the supply of raw materials using the simple additive weighting (SAW) method. This application was developed with the Power Builder 8.0 programming language and Sybase SQL Anyware 5.0 as its database. The results of this study are able to help system users determine the priority of the supply of raw materials in order to facilitate the production process.
\end{abstract}

Keywords: Decision Support System, Priority of Supply of Raw Materials, Simple Additive Weighting (SAW), Power Builder, Sybase SQL Anyware Database

(C)2019 Sani, Munandar, Suhendar

This is an open access article under the CC-BY-NC-SA license. 


\begin{abstract}
ABSTRAKSI
Semakin banyaknya jenis bahan baku yang akan digunakan untuk memperlancar proses produksi sepatu, membuat perusahaan kesulitan dalam menentukan prioritas bahan baku. Sehingga sering terjadi kelebihan dan kekurangan bahan baku pada saat proses produksi, yang menyebabkan adanya perubahan anggaran biaya produksi yang tidak sesuai dengan perencanaan awal sehingga mengakibatkan keuntungan perusahaan menurun. Sistem Pendukung Keputusan (SPK) adalah sistem yang dapat membantu seseorang dalam mengambil keputusan yang akurat dan tepat sasaran. Banyak permasalahan yang dapat diselesaikan dengan menggunakan SPK, salah satunya adalah penentuan prioritas penyediaan bahan baku. Ada beberapa metode yang dapat digunakan dalam membangun suatu SPK, diantaranya simple addtive weighting (SAW). Metode Simple Additive Weighting (SAW) sering juga dikenal dengan istilah metode penjumlahan terbobot, dengan mencari penjumlahan terbobot dari rating kinerja pada setiap alternatif dari semua atribut. Penelitian ini membahas tentang pembuatan sistem pendukung keputusan sebagai alat bantu untuk penentuan prioritas penyediaan bahan baku menggunakan metode simple additive weighting (SAW). Aplikasi ini dikembangkan dengan bahasa pemrograman Power Builder 8.0 dan Sybase SQL Anyware 5.0 sebagai database nya. Hasil penelitian ini mampu membantu pengguna sistem dalam menentukan prioritas penyediaan bahan baku guna memperlancar jalannya proses produksi
\end{abstract}

Keywords: Sistem Pedukung Keputusan, Prioritas Penyediaan Bahan Baku, Simple Additive Weighting (SAW), Power Builder, Database Sybase SQL Anyware

\title{
1 Pendahuluan
}

Berkembangnya industri sepatu saat ini, menuntut perusahaan memproduksi sepatu berkualitas dengan harga jual yang bersaing. Bagi perusahaan atau industri seperti PT.Parkland World Indonesia, kelangsungan proses produksi dipengaruhi oleh beberapa faktor, salah satunya ketersediaan bahan baku produksi yang memadai.

Selama ini perusahaan PT. Parkland World Indonesia melakukan perencanaan dan pengendalian persediaan bahan baku menggunakan metode MRP. Akan tetapi penggunaan metode tersebut belum maksimal, karena masih sering terjadi kelebihan dan kekurangan bahan baku sehingga menyebabkan terjadinya perubahan anggaran biaya produksi yang tidak sesuai dengan perencanaan awal. Disamping itu kelebihan pengadaan bahan baku berdasarkan perhitungan metode MRP, mengakibatkan bahan baku yang tersisa tidak terpakai. Selain itu, kekurangan-kekurangan yang terjadi dapat mengganggu atau menghambat proses produksi dalam memenuhi permintaan konsumen. Kekurangan bahan baku juga dapat menimbulkan terjadinya pembengkakan biaya, karena pada umumnya pesanan secara mendadak akan lebih mahal dibandingkan dengan pesanan yang normal, akibatnya keuntungan perusahaan akan menurun.

Perkembangan ilmu komputer saat ini, memberikan peluang untuk membantu menyelesaikan berbagai permasalahan dunia nyata. Selain itu ilmu komputer juga dapat memberikan solusi bagi para pelaku bisnis dalam menentukan langkah yang tepat untuk menentukan suatu keputusan. Dalam hal ini permasalahan yang ada pada PT. Parkland World Indonesia tentu dapat diselesaikan dengan pendekatan ilmu komputer, salah satunya adalah dengan metode Simple Additive Weighting ( SAW ).

Metode Simple Additive Weighting (SAW) sering juga dikenal dengan istilah metode penjumlahan terbobot, dengan mencari penjumlahan terbobot dari rating kinerja pada setiap alternatif dari semua atribut. Serta membutuhkan proses normalisasi matrik keputusan (X) ke suatu skala yang dapat diperbandingkan dengan semua rating alternatif yang ada (Kusumadewi dkk, 2006).

Penelitian ini bertujuan untuk membangun sebuah Sistem Pendukung Keputusan menggunakan metode Simple Additive Weighting. Sistem pendukung keputusan ini digunakan sebagai alat bantu bagi perusahaan dalam pengambilan keputusan pada proses penentuan persediaan bahan baku pada PT. Parkland World Indonesia.

Beberapa penelitian menggunakan Sistem Pendukung Keputusan dan Simple Additive Weighting misalnya untuk pendukung keputusan penerima beasiswa (Pahlevy, 2011; Prayogo, 2011), simulasi faktor penentu keberhasilan personil yang mempengaruhi kualitas dan karyawan terbaik (Afshari, 2010; Jasril, 2011), pemilihan tanaman obat (Apriani, 2010), pemilihan sepeda motor (Sari, 2012), pemeliharaan industri kecil dan menengah (Tahir dan Febrianto, 2009), penentuan lokasi pendirian warnet (Winiarti, 2009), pendukung keputusan dalam penerimaan karyawan (Maharrani, 2010), pemilihan sekolah tinggi 
(Astuti, 2011) dan pendukung keputusan untuk penentun kelulusan ujian saringan masuk universitas (Rumaisa, 2010)..

Penelitian ini terbagi ke dalam tujuh bagian. Bagian pertama menjelaskan tentang latar belakang permasalahan terkait topik penelitian yang diambil. Bagian kedua sampai keempat merupakan landasarn teori yang digunakan dalam penelitian. Bagian kelima menjelaskan langkah penelitian yang dilakukan. Bagian keenam membahas hasil dan diskusi penelitian. Dibagian terakhir dibahas kesimpulan yang juga memuat saran penelitian dimasa mendatang.

\section{Dasar Teori}

\subsection{Sistem Pendukung Keputusan}

Sistem Pendukung Keputusan (SPK) atau Decision Support System (DSS) adalah sebuah sistem yang mampu memberikan kemampuan pemecahan masalah maupun kemampuan pengkomunikasian untuk masalah dengan kondisi semi terstruktur dan tak terstruktur. Sistem ini digunakan untuk membantu pengambilan keputusan dalam situasi semi terstruktur dan situasi yang tidak terstruktur, dimana tak seorangpun tahu secara pasti bagaimana keputusan seharusnya dibuat (Turban dkk, 2007).

Sistem pendukung keputusan terdiri atas 3 komponen utama atau sub-sistem, yaitu:

1. Sub-sistem Data (Data Base)

Sub-sistem data merupakan komponen sistem pendukung keputusan sebagai penyedia data bagi sistem. Data disimpan dalam suatu rangkaian data (Data Base) yang diorganisasikan oleh suatu sistem yaitu Sistem Manajemen Pangkalan Data (Data Base Management System). Pangkalan data dalam sistem pendukung keputusan berasasal dari dua sumber yaitu sumber internal (dari dalam organisasi atau perusahaan) dan sumber eksternal (dari organisasi atau perusahaan).

2. Sub-sistem Model (Model Base)

Model adalah suatu peniru dari alam nyata. Pengolahan berbagai model dilakukan dalam pengkalan model. Penyimpananberbagai model dalam pangkalan model dilakukan secara fleksibel untuk membantu pengguna dalam memodifikasi dan menyempurnakan model.

3. Sub-sistem Dialog (User System Interface)

Sub-sitem dialog adalah fasilitas yang mampu mengintegrasikan sistem yang terpasang dengan user secara interaktif. Melalui subsitem dialog inilah sistem diartikulasi dan di implementasikan sehingga pengguna dapat berkomunikasi dengan sistem yang dirancang Aplikasi Sistem pendukung keputusan menggunakan data, memberikan antar muka pengguna yang mudah dan dapat menggabungkan pemikiran pengambilan keputusan. Sistem pendukung keputusan lebih ditujukan untuk mendukung manajemen dalam melakukan pekerjaan yang bersifat analitis dalam situasi yang kurang terstruktur dan dengan kriteria yang kurang jelas.

\subsection{Persediaan}

Persediaan dapat diartikan sebagai barang-barang yang disimpan untuk digunakan atau dijual pada masa atau periode yang akan datang. Persediaan terdiri dari persediaan bahan baku, persediaan bahan setengah jadi dan persediaan barang jadi. Persediaan bahan baku dan bahan setengah jadi disimpan sebelum digunakan atau dimasukkan ke dalam proses produksi, sedangkan persediaan barang jadi atau barang dagangan disimpan sebelum dijual atau dipasarkan.

Dengan demikian setiap perusahaan yang melakukan kegiatan usaha umumnya memiliki persediaan. Persediaan merupakan suatu model yang umum digunakan untuk menyelesaikan masalah yang terkait dengan usaha pengendalian bahan baku maupun barang jadi dalam suatu aktifitas suatu Perusahaan. Maka dapat diambil kesimpulan bahwa pengertian pengendalian persediaan merupakan suatu usaha memonitor dan menentukan tingkat komposisi bahan yang optimal dalam menunjang kelancaran dan efektifitas serta efisiensi dalam kegiatan suatu Perusahaan.

Untuk menjamin kelancaran dan kesinambungan produksi, maka baik perusahaan dagang maupun manufaktur perlu mengadakan persediaan karena persediaan merupakan unsur modal kerja yang sangat penting dan yang secara kesinambungan akan berputar dalam siklus perputaran modal kerja perusahaan.

Secara umum dapat dikatakan bahwa tujuan dari pengendalian adalah untuk menekan biaya-biaya operasional seminimal mungkin sehingga akan mengoptimalisasikan kinerja perusahaan. Untuk melaksanakan pengendalian persediaan yang dapat diandalkan dan dipercaya tersebut maka harus diperhatikan berbagai faktor yang terkait dengan persediaan. Penentuan dan pengelompokan biaya-biaya 
yang terkait dengan persediaan perlu mendapatkan perhatian yang khusus dari pihak manajemen dalam mengambil keputusan yang tepat.

\subsection{Simple Additive Weighting (SAW)}

Salah satu metode penyelesaian masalah MADM adalah dengan menggunakan metode Simple Additive Weighting (SAW). Metode SAW sering juga dikenal istilah metode penjumlahan terbobot. Konsep dasar metode SAW adalah mencari penjumlahan terbobot dari rating kinerja pada setiap alternatif dari semua atribut. Metode SAW membutuhkan proses normalisasi matriks keputusan (X) ke suatu skala yang dapat diperbandingkan dengan semua rating alternatif yang ada (Kusumadewi dkk, 2006).

Langkah Penyelesaian Simple Additive Weighting (SAW) adalah sebagai berikut :

1) Menentukan kriteria-kriteria yang akan dijadikan acuan dalam pengambilan keputusan, yaitu $\mathrm{C}_{\mathrm{i}}$.

2) Menentukan rating kecocokan setiap alternatif pada setiap kriteria.

3) Membuat matriks keputusan berdasarkan kriteria $\left(\mathrm{C}_{\mathrm{i}}\right)$, kemudian melakukan normalisasi matriks berdasarkan persamaan yang disesuaikan dengan jenis atribut (atribut keuntungan ataupun atribut biaya) sehingga diperoleh matriks ternormalisasi R.

4) Hasil akhir diperoleh dari proses perankingan yaitu penjumlahan dari perkalian matriks ternormalisasi $\mathrm{R}$ dengan vektor bobot sehingga diperoleh nilai terbesar yang dipilih sebagai alternatif terbaik (Ai) sebagai solusi.

Formula untuk melakukan normalisasi tersebut adalah :

$$
r_{i j}= \begin{cases}\frac{x_{i j}}{\operatorname{Max} x_{i j}} & \text { Jika j adalah atribut keuntungan ( benefit) } \\ \frac{\operatorname{Min} x_{i j}}{x_{i j}} & \text { Jika j adalah atribut biaya (cost) }\end{cases}
$$

Dimana :

$$
\begin{array}{ll}
\mathrm{r}_{\mathrm{ij}} & =\text { rating kinerja ternormalisasi } \\
\operatorname{Max}_{\mathrm{ij}} & =\text { nilai maksimum dari setiap baris dan kolom } \\
\operatorname{Min}_{\mathrm{ij}} & =\text { nilai minimum dari setiap baris dan kolom } \\
\mathrm{X}_{\mathrm{ij}} & =\text { baris dan kolom dari matriks }
\end{array}
$$

$r_{i j}$ adalah rating kinerja ternormalisasi dari alternatif Ai pada atribut $C_{j} ; i=1,2, \ldots, m$ dan $j=1,2, \ldots, n$.Nilai preferensi untuk setiap alternatif $\left(\mathrm{V}_{\mathrm{i}}\right)$ diberikan sebagai:

$$
V_{i}=\sum_{j=1}^{n} w_{j} r_{i j}
$$

Dimana :

$$
\begin{array}{ll}
\mathrm{V}_{\mathrm{i}} & =\text { Nilai akhir dari alternatif } \\
\mathrm{w}_{\mathrm{j}} & =\text { Bobot yang telah ditentukan } \\
\mathrm{r}_{\mathrm{ij}} & =\text { Normalisasi matriks }
\end{array}
$$

Nilai $\mathrm{V}_{\mathrm{i}}$ yang lebih besar mengindikasikan bahwa alternatif $\mathrm{A}_{\mathrm{i}}$ lebih terpilih.

\section{Metodologi Penelitian}

Penelitian ini diawali dengan melakukan Studi pendahuluan, yaitu tahap awal dalam metodologi penelitian ini. Di tahap ini peneliti melakukan studi lapangan dengan terjun langsung ke perusahaan. Pengamatan langsung maupun wawancara adalah hal-hal yang dilakukan dengan tujuan mengetahui informasi-informasi awal mengenai perusahaan agar dalam hal ini, secara jelas dapat memahami mengenai bidang industri PT. Parkland World Indonesia, produk yang dihasilkan oleh PT. Parkland World Indonesia, struktur organisasi PT. Parkland World Indonesia beserta strategi yang diambil dalam menjalankan aktivitas bisnis mereka, maupun permasalahan yang dihadapi PT. Parkland World Indonesia. Dari berbagai masalah yang ditemukan, peneliti kemudian memilih satu masalah utama sebagai tolak ukur dalam penelitian ini, untuk selanjutnya dicari solusi penyelesaiannya. Studi pendahuluan ini berguna untuk mempermudah identifikasi masalah sebagai panduan untuk mengerjakan tahap-tahap selanjutnya. Selanjutnya peneliti melakukan Identifikasi dan perumusan masalah berdasarkan informasi-informasi yang didapat dari tahap studi pendahuluan sebelumnya, kemudian dilakukan identifikasi permasalahan yang 
sedang dihadapi perusahaan yang kemudian akan diteruskan dengan perumusan masalah yang dihadapi perusahaan. Setelah dilakukan identifikasi masalah, maka secara lebih khusus diketahui bahwa masalah yang dihadapi oleh perusahaan yaitu masih kurang terorganisirnya metode MRP yang digunakan perusahaan dalam penentuan persediaan bahan baku.

Setelah melakukan identifikasi dan perumusan masalah dalam perusahaan, langkah selanjutnya adalah mencari informasi pada buku-buku referensi, baik berupa text book, literatur, diktat, jurnal, informasi dari internet maupun sumber-sumber lainnya seperti diskusi dengan dosen dan peneliti lain yang dapat membantu dalam mengatasi permasalahan yang sedang dihadapi perusahaan. Studi pustaka bertujuan untuk memperoleh metode-metode dan pendekatan yang memadai untuk membantu peneliti dalam memecahkan masalah yang sedang dihadapi perusahaan. Hasil dari studi pustaka ini akan dimasukkan dalam landasan teori dalam penelitian.

Langkah selanjutnya yaitu melakukan pengumpulan data, tahap ini dilakukan pengumpulan data dari perusahaan yang dibutuhkan untuk melakukan pengolahan data untuk memecahkan masalah di perusahaan. Proses pengumpulan data ini dilakukan baik dengan dokumentasi, wawancara, maupun observasi langsung yang dilakukan pada bagian Marketing, Produksi, dan Gudang. Setelah melakukan pengumpulan data maka peneliti akan melakukan pengembangan sistem, metode pengembangan sistem yang digunakan dalam penelitian ini ialah Pemodelan berorientasi objek menggunakan tools UML (Unified Modelling Language).

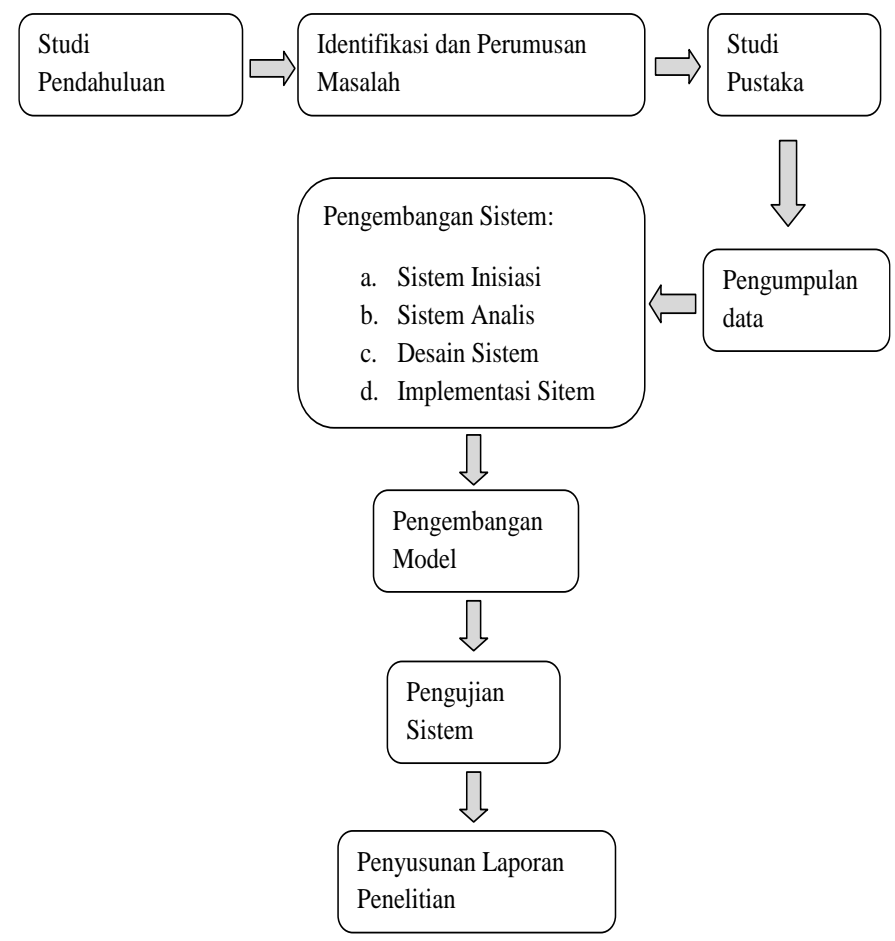

Gambar 1. Skema penelitian

Proses selanjutnya yaitu melakukan pengembangan model, Metode pengembangan model yang digunakan ialah dengan metode Simple Additive Weighting (SAW). Metode Simple Additive Weighting (SAW) sering juga dikenal istilah metode penjumlahan terbobot. Konsep dasar metode SAW adalah mencari penjumlahan terbobot dari rating kinerja pada setiap alternatif pada semua atribut (Fishburn, 1967) (MacCrimmon, 1968). Metode SAW membutuhkan proses normalisasi matriks keputusan (X) ke suatu skala yang dapat diperbandingkan dengan semua rating alternatif yang ada. Metode ini merupakan metode yang paling banyak digunakan dalam menghadapi situasi Multiple Attribute Decision Making (MADM) yang mengharuskan pengambil keputusan menentukan bobot bagi setiap atribut. Skor total untuk alternatif diperoleh dengan menjumlahkan seluruh hasil perkalian antara rating (yang dapat dibandingkan lintas atribut) dan bobot tiap atribut. Rating tiap atribut haruslah bebas dimensi dalam arti telah melewati proses normalisasi matriks sebelumnya. Kemudian peneliti melakukan Pengujian Sistem setelah perangkat lunak 
dibuat dengan menggunakan bahasa pemograman, maka perangkat lunak tersebut perlu diuji dan diaplikasikan untuk menunjukkan kesesuaian sistem dengan persoalan. Perangkat lunak tersebut dapat diuji dengan cara black box test. Berikut adalah skema penelitian yang dilakukan (lihat Gambar 1).

\section{Hasil dan Pembahasan}

\subsection{Analisis Perhitungan Metode SAW}

Kasus : Perusahaan PT. Parkland World Indonesiaakan melakukan prioritas penyediaan bahan baku terhadap 7 Jenis bahan baku untuk kebutuhan proses produksi sepatu. Agar proses produksi sepatu di PT. Parkland World Indonesia dapat berjalan lancar, maka pengambil keputusan harus menentukan 5 jenis bahan baku utama yang harus di pesan kepada supplier. dengan metode SAW diharuskan pengambil keputusan dapat menentukan jenis bahan baku mana yang harus di prioritaskan.

\subsection{Perhitungan Metode SAW}

Proses perhitungan dengan menggunakan metode SAW diawali dengan menentukan kriteria-kriteria yang akan dijadikan acuan dalam pengambilan keputusan dan menentukan rating kecocokan setiap alternatif pada setiap kriteria (memberi bobot nilai dari setiap alternatif dengan kriteria yang telah ditentukan.

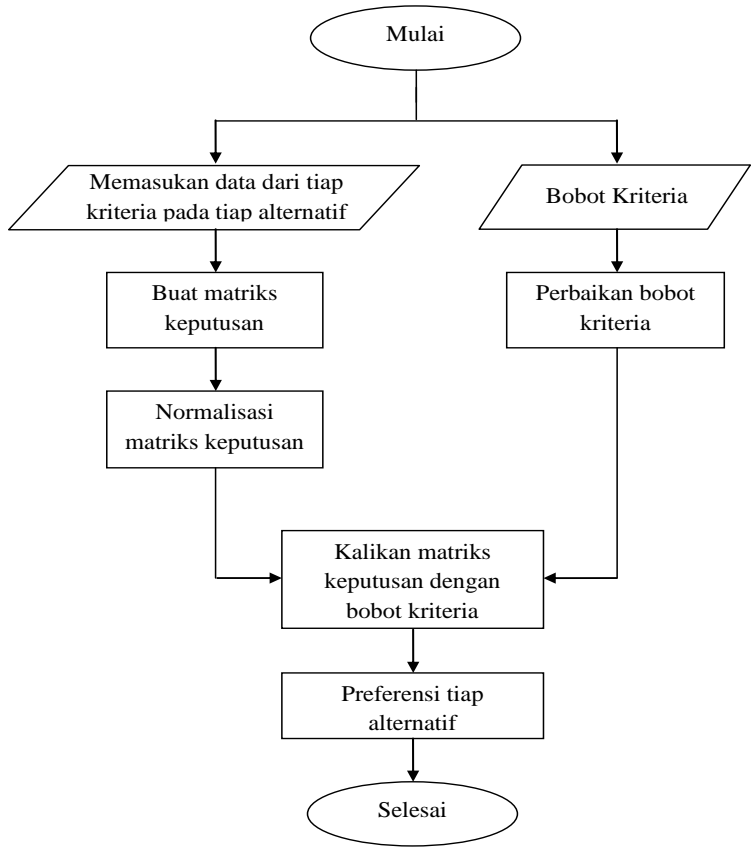

Gambar 2. Proses perhitungan SAW

Proses selanjutnya yaitu membuat matriks keputusan berdasarkan kriteria, kemudian melakukan normalisasi matriks berdasarkan persamaan yang disesuaikan dengan jenis atribut (atribut keuntungan ataupun atribut biaya) sehingga diperoleh matriks ternormalisasi R. Sedangkan hasil akhir diperoleh dari proses perankingan yaitu penjumlahan dari perkalian matriks ternormalisasi $\mathrm{R}$ dengan vektor bobot sehingga diperoleh nilai terbesar yang dipilih sebagai alternatif terbaik sebagai solusi. Proses perhitungan metode SAW dapat ditunjukan pada Gambar 2.

Sebelum melakukan proses perhitungan metode SAW, pengambil keputusan harus menentukan kriteria benefit dan kriteria cost nya:

Kriteria benefit-nya adalah :

- $\operatorname{Order}(\mathrm{C} 1)$

- Export date (C2)

- Shortage (C3) 
Sedangkan kriteria cost-nya adalah :

- Poor process $(\mathrm{C} 4)$

- B-Grade (C5)

Tabel 1. Pembobotan Kriteria

\begin{tabular}{|c|c|c|c|c|c|}
\hline \multirow{2}{*}{$\begin{array}{c}\text { Calon } \\
\text { Pegawai }\end{array}$} & \multicolumn{5}{|c|}{ Kriteria } \\
\cline { 2 - 6 } & C1 & C2 & C3 & C4 & C5 \\
\hline A1 & 200.179 & 47.194 & 28.597 & 14.298 & 14.182 \\
\hline A2 & 185.88 & 42.895 & 25.737 & 12.868 & 11.438 \\
\hline A3 & 171.582 & 40.216 & 21.786 & 11.682 & 11.141 \\
\hline A4 & 190.477 & 36.762 & 22.136 & 11.142 & 10.216 \\
\hline A5 & 194.459 & 36.182 & 20.428 & 9.872 & 9.173 \\
\hline A6 & 188.790 & 32.176 & 20.141 & 9.071 & 8.971 \\
\hline A7 & 187.740 & 32.016 & 19.617 & 8.762 & 8.112 \\
\hline
\end{tabular}

Pembobotan (w) : Pembobotan ini ialah pembobotan tiap-tiap kriteria. Jadi jika perusahaan ingin menentukan prioritas jenis bahan baku berdasarkan Order sepatu dan Shortage, maka perusahaan harus mengutamakan Order. dan Order diberi bobot lebih tinggi daripada Shortage.

Tabel 2. Matriks Nilai Bobot Kriteria

\begin{tabular}{|c|c|}
\hline Kriteria & Bobot \\
\hline C1 & 0,3 \\
\hline C2 & 0,25 \\
\hline C3 & 0,2 \\
\hline C4 & 0,15 \\
\hline C5 & 0,1 \\
\hline Total & $\mathbf{1}$ \\
\hline
\end{tabular}

Tabel pertama (pembobotan alternatif terhadap kriteria) diubah kedalam bentuk matriks. Matriks Keputusan diperoleh sebagai berikut :

$\left\{\begin{array}{lllll}200.179 & 47.194 & 28.597 & 14.298 & 14.182 \\ 185.88 & 42.895 & 25.737 & 12.868 & 11.438 \\ 171.582 & 40.216 & 21.786 & 11.682 & 11.141 \\ 190.477 & 36.762 & 22.136 & 11.142 & 10.216 \\ 194.459 & 36.182 & 20.428 & 9.872 & 9.173 \\ 188.790 & 32.176 & 20.141 & 9.071 & 8.971 \\ 187.740 & 32.016 & 19.617 & 8.762 & 8.112\end{array}\right\}$

Untuk kriteria benefitnya yaitu (C1, C2 dan C3). Untuk normalisai nilai, jika faktor kriteria benefit, maka digunakanan persamaan (1)

Dari kolom C1 nilai maksimalnya adalah '200.179', maka tiap baris dari kolom C1 dibagi oleh nilai maksimal kolom C1 
$\mathrm{R} 11=200.179 / 200.179=1$
$\mathrm{R} 21=185.880 / 200.179=0.92$
$\mathrm{R} 31=171.582 / 200.179=0.85$
$\mathrm{R} 41=190.477 / 200.179=0.95$
$\mathrm{R} 51=194.459 / 200.179=0.97$
$\mathrm{R} 61=188.790 / 200.179=0.94$
$\mathrm{R} 71=187.740 / 200.179=0.94$

Dari kolom C2 nilai maksimalnya adalah '47.194', maka tiap baris dari kolom C2 dibagi oleh nilai maksimal kolom C2

$\mathrm{R} 12=47.194 / 47.194=1$

$\mathrm{R} 22=42.895 / 47.194=0.91$

$\mathrm{R} 32=40.216 / 47.194=0.85$

$\mathrm{R} 42=36.182 / 47.194=0.78$

$\mathrm{R} 52=36.176 / 47.194=0.77$

$\mathrm{R} 62=32.176 / 47.194=0.68$

$\mathrm{R} 72=32.016 / 47.194=0.68$

Dari kolom C3 nilai maksimalnya adalah '28.597', maka tiap baris dari kolom C3 dibagi oleh nilai maksimal kolom C3

$\mathrm{R} 13=28.597 / 28.597=1$

$\mathrm{R} 23=25.737 / 28.597=0.90$

$\mathrm{R} 33=21.786 / 28.597=0.76$

$\mathrm{R} 43=22.136 / 28.597=0.77$

$\mathrm{R} 53=20.428 / 28.597=0.71$

$\mathrm{R} 63=20.141 / 28.597=0.70$

$\mathrm{R} 73=19.617 / 28.597=0.69$

Sedangkan kriteria costnya yaitu (C4 dan C5). Untuk normalisai nilai, jika vektor kriteria cost digunakan persamaan (1) :

Dari kolom C4 nilai minimalnya adalah ' 8.762 ', maka tiap baris dari kolom C5 menjadi penyebut dari nilai maksimal kolom C5

$$
\begin{aligned}
& \mathrm{R} 14=8.762 / 14.298=0.61 \\
& \mathrm{R} 24=8.762 / 12.868=0.68 \\
& \mathrm{R} 34=8.762 / 11.682=0.75 \\
& \mathrm{R} 44=8.762 / 11.142=0.79 \\
& \mathrm{R} 54=8.762 / 9.872=0.89 \\
& \mathrm{R} 64=8.762 / \quad 9.071=0.97 \\
& \mathrm{R} 74=8.762 / \quad 8.762=1
\end{aligned}
$$

Dari kolom C5 nilai minimalnya adalah ' 8.112 ', maka tiap baris dari kolom C5 menyadi penyebut dari nilai maksimal kolom C5

$$
\begin{aligned}
& \mathrm{R} 15=8.112 / 14.182=0.57 \\
& \mathrm{R} 25=8.112 / 11.438=0.71 \\
& \mathrm{R} 35=8.112 / 11.141=0.73 \\
& \mathrm{R} 45=8.112 / 10.216=0.79 \\
& \mathrm{R} 55=8.112 / 9.173=0.88 \\
& \mathrm{R} 45=8.112 / 8.971=0.90 \\
& \mathrm{R} 55=8.112 / 8.112=1
\end{aligned}
$$


Masukan semua hasil penghitungan tersebut kedalam tabel yang disebut tabel Vektor ternormalisasi seperti pada Tabel 3.

Tabel 3. Vektor Ternomalisasi

\begin{tabular}{|c|c|c|c|c|c|}
\hline \multirow{2}{*}{$\begin{array}{c}\text { Calon } \\
\text { Pegawai }\end{array}$} & \multicolumn{5}{|c|}{ Kriteria } \\
\cline { 2 - 6 } A1 & 1 & 1 & 1 & 0.61 & 0.57 \\
\hline $\mathbf{A 2}$ & 0.93 & 0.91 & 0.90 & 0.68 & 0.71 \\
\hline $\mathbf{A 3}$ & 0.85 & 0.85 & 0.76 & 0.75 & 0.73 \\
\hline $\mathbf{A 4}$ & 0.95 & 0.78 & 0.77 & 0.79 & 0.79 \\
\hline $\mathbf{A 5}$ & 0.97 & 0.77 & 0.71 & 0.89 & 0.88 \\
\hline $\mathbf{A 6}$ & 0.94 & 0.68 & 0.70 & 0.97 & 0.9 \\
\hline $\mathbf{A 7}$ & 0.94 & 0.68 & 0.69 & 1 & 1 \\
\hline
\end{tabular}

Setelah mendapat tabel seperti diatas, maka kalikanlah setiap kolom di tabel tersebut dengan bobot kriteria yang telah di deklarasikan sebelumnya. Gunakan persamaan (5) untuk menghitung nilai alternatif dari bobot terhadap kriteria. Sehingga diperoleh sebagai berikut :

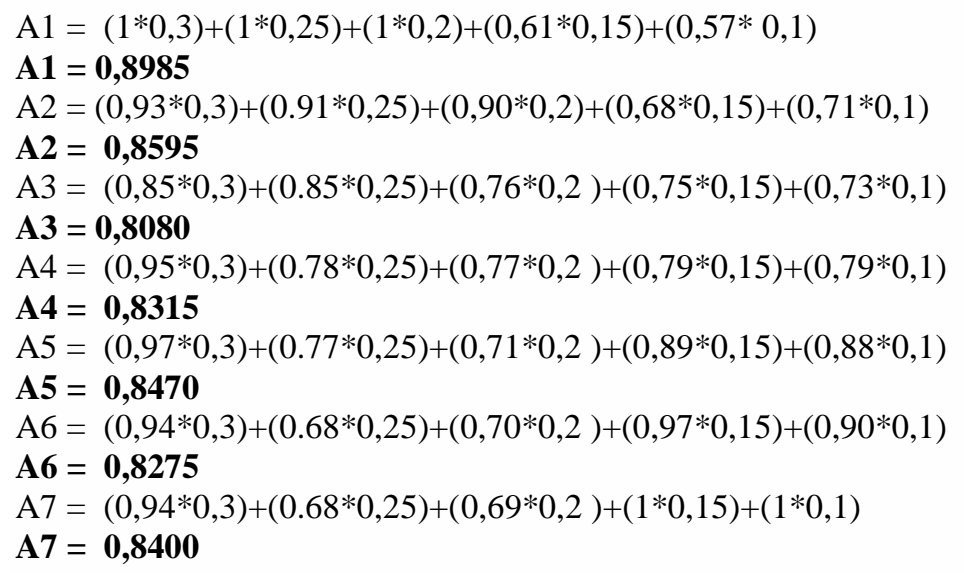

Dari perbandingan nilai akhir, maka didapatkan nilai sebagai berikut:

$\mathrm{A} 1=0,8985$

$\mathrm{A} 2=0,8595$

$\mathrm{A} 3=0,8080$

$\mathrm{A} 4=0,8315$

$\mathrm{A} 5=0,8470$

$\mathrm{A} 6=0,8275$

$\mathrm{A} 7=0,8400$

Maka alternatif yang memiliki nilai tertinggi dan bisa dipilih adalah alternatif A1 dengan nilai 0,8985 dan alternatif A2 dengan nilai 0,8595.

\section{Kesimpulan}

Berdasarkan hasil penelitian, analisis, perancangan sistem, pembuatan program sampai tahap penyelesaian program, maka dapat diambil kesimpulan sebagai berikut :

Setelah melakukan pengujian dari beberapa proses utama yang menggunakan perhitungan dan analisis dengan melibatkan perhitungan secara manual, dapat diketahui bahwa hasil yang didapatkan dari perhitungan manual sama dengan perhitungan oleh sistem. Sehingga secara umum sistem telah bekerja 
dengan baik karena proses perhitungan telah sesuai dengan yang diharapkan. Aplikasi ini juga mampu mengolah data alternatif terbaik dari sejumlah alternatif yang adanya karena proses perengkingan setelah menentukan nilai bobot untuk setiap kriteria. Setelah menentukan nilai bobot dan mengisi jumlah kriteria pada setiap alternatif, maka sistem dapat mengolah proses perhitungan vektor ternormalisasi sehingga menghasilkan nilai alternatif terbaik dari sejumlah alternatif yang ada. Sistem ini juga dapat menjadi sarana penyimpanan data-data tersebut sehingga dapat didokumentasikan dan dipertanggungjawabkan. Dari pengolahan data alternatif dan data kriteria ini, dapat disimpulkan bahwa sistem ini mampu membantu manajemen dalam mengambil kebijakan atau keputusan bisnis yang terkait dengan perencanaan bahan baku yang terstruktur.Sistem ini akan membantu manager atau atasan untuk mengetahui dan menentukan prioritas alternatif atau jenis bahan baku yang harus diprioritaskan untuk persediaan bahan baku guna membantu kelancaran proses produksi.

\section{References}

Kusumadewi, Hartati, S., Harjoko, A., dan Wardoyo, R. 2006. Fuzzy Multi-Atribute Decision Making (Fuzzy MADM). Yogyakarta: Graha Ilmu.

Eniyati. 2011. Production Planning and Inventory Control. PT Gramedia Pustaka Utama, Jakarta.

Nugraha. 2011. Sistem Pendukung Keputusan Dengan Metode Simple Additive Weighting (SAW) dalam Manajemen Aset, UDS Semarang.

Wibowo. 2010. Komputerisasi Pengambilan Keputusan. PT. Elexmedia Komputindo, Jakarta.

Mamariani., Relina, T. 2009 Analisis sensitivitas masalah MADM, Universitas Akhmad Dahlan, Yogyakarta.

Afshari, K. 2010 Sistem Pendukung Keputusan pada Simulasi faktor kunci keberhasilan pemilihan personil bagi suatu organisasi yang mempengaruhi kualitas karyawan, UDS Semarang

Pahlevy. 2011. Rancang Bangun Sistem Pendukung Keputusan Untuk Menentukan Penerima Beasiswa Dengan Menggunakan Metode Simple Additive Weighting (SAW). UNIVERSITAS PEMBANGUNAN NASIONAL"VETERAN" JAWA TIMUR.

Apriani, K.S. 2010. Rancang Bangun Aplikasi Sistem Pendukung Keputusan Pemilihan Alternatif Tanaman Obat Berbasis WEB, Universitas Siliwangi, Tasikmalaya.

Tahir, T., dan Febrianto, S. 2009. Sistem Pendukung Keputusan Pemeliharaan untuk Industri Kecil dan Menengah dengan Gabungan model Optimasi. UNHAS Malaysia.

Sari. 2012. Sistem Pendukung Keputusan (SPK) Pemilihan Sepeda Motor dengan menggunakan Metode AHP. UAD Yogyakarta.

Winiarti, Y. 2009. Aplikasi Sistem Pendukung Keputusan Penentuan Lokasi Pendirian Warnet dengan metode AHP. UAD Yogyakarta.

Maharrani, D. 2010. Penerapan Metode AHP dalam penerimaan Karyawan Pada PT. PASIR BESI INDONESIA. Universitas Dian Nuswantoro Semarang.

Prayogo. 2011. Sistem Pendukung Keputusan Untuk Menentukan Penerima Beasiswa menggunakan Algoritma Genetika dengan Metode Fuzzy Logic Sebagai Inisialisasi. UPI Bandung.

Jasril, K. 2011. Sistem Pendukung Keputusan Pemilihan Karyawan terbaik menggunakan metode Fuzzy AHP. UIN Sultan Syarif Kasim Riau.

Astuti, A. 2011. AHP untuk Pemodelan SPK pemilihan sekolah tinggi Komputer. STMIK AMIKOM Yogyakarta.

Turban, E., Aronson, E.J., dan Liang-Ting, P. 2007. Decicion Support Systems and Intelligent Systems: Seventh Edition. India: Prentice-Hall.

Rumaisa, N. 2010. Sistem Pendukung Keputusan Kelulusan Ujian Saringan Masuk Jalur PMDK Berdasarkan Nilai Rata-rata Matematika dan Bahasa Inggris. Universitas Widyatama Bandung. 